\title{
The Periodic Table is on Campus How everyone can learn a little bit of chemistry
}

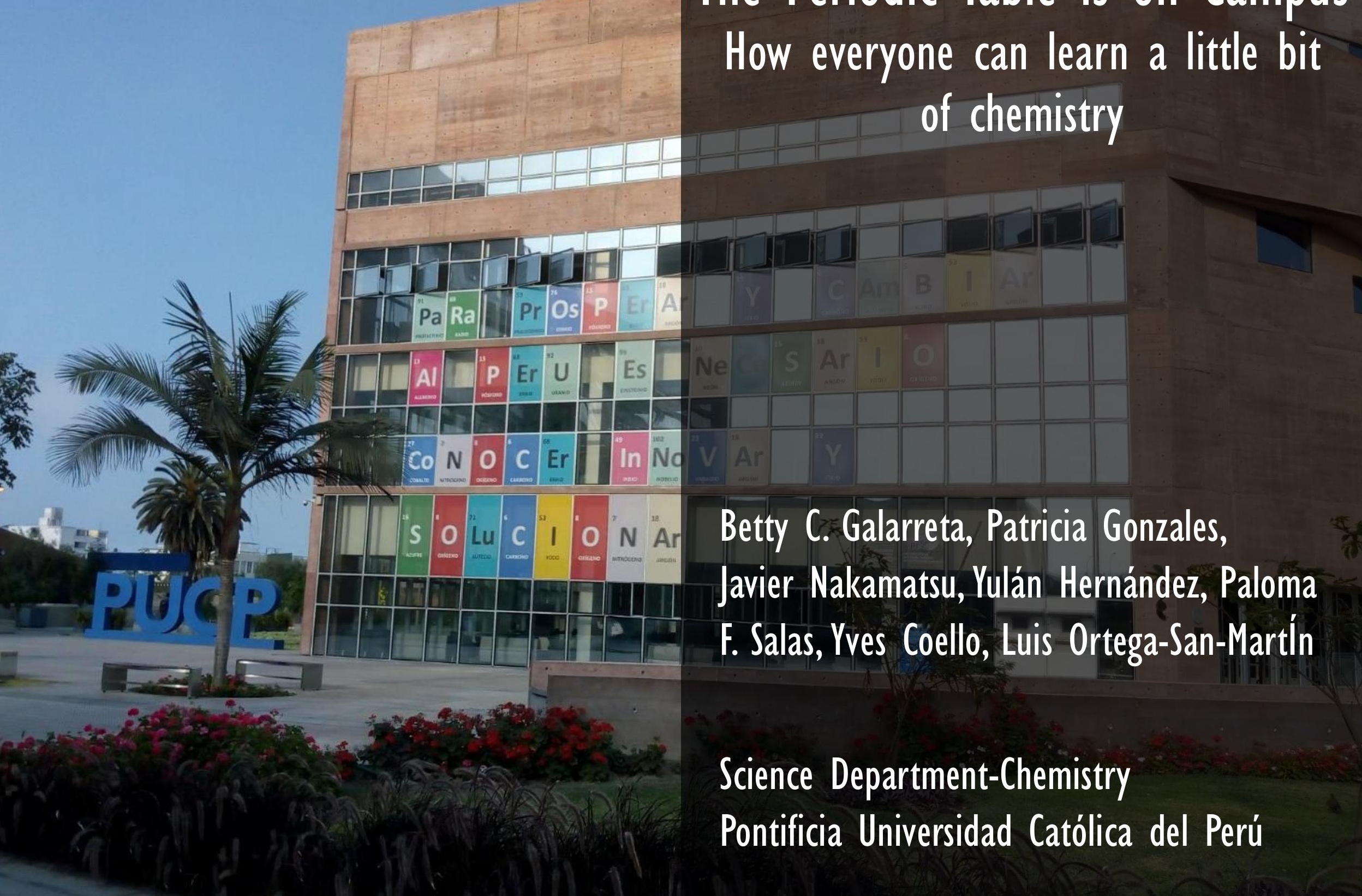




\section{Our goals}

SCIENCE - SOCIETY - WORLD - SUSTAINABLE DEVELOPMENT

- To enhance public interest in Chemistry

- To engage our community with the periodic table

- To promote the role Chemistry has in our daily lives

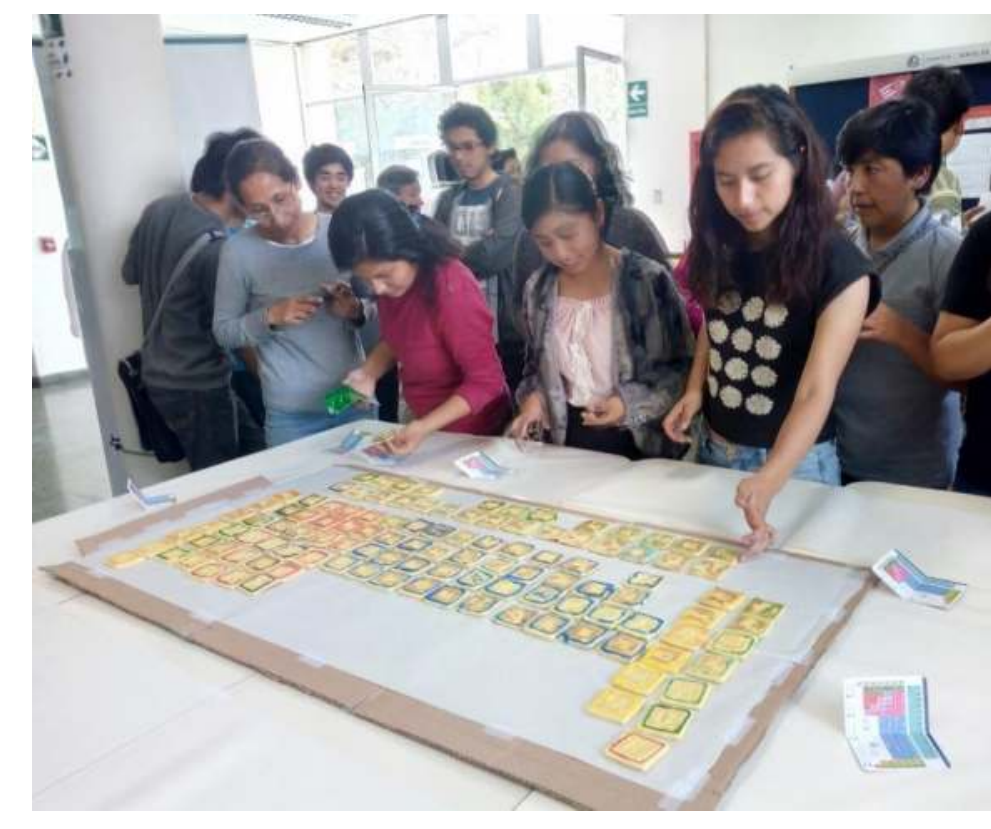




\section{Phrases made only with the element symbols of the Periodic Table}

- Participants

Students, faculty \& staff

- Task

- Result

To write a phrase related to science, research and PUCP

Display of winning phrase in the Science Library windows, in

environmentally friendly bags and bookmarks

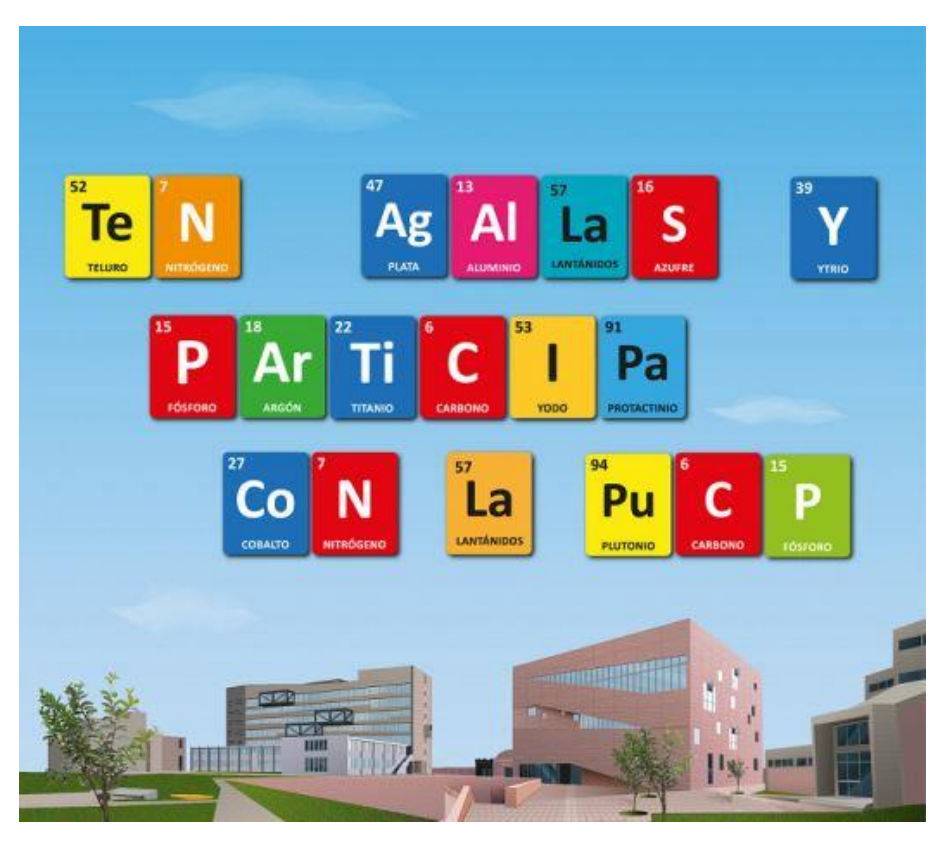



Bryan A. León

Management Faculty

Admission Office staff member

“La PUCP investiga, participa y colabora para las generaciones posteriores"

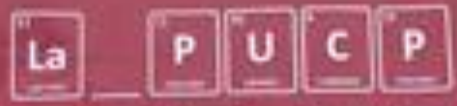

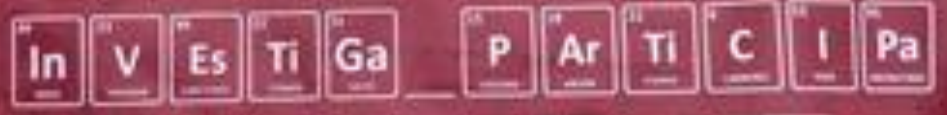 Y Y Co L

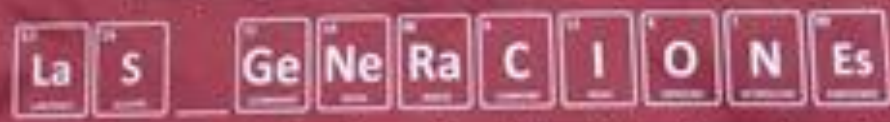

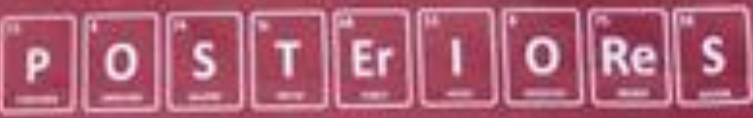

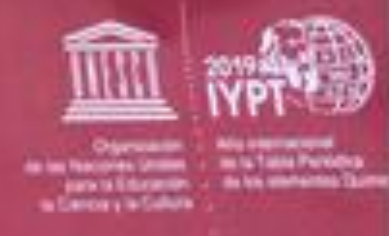

(PUCP investigates, participates and collaborates for the next generations) 
Brenda D'Acunha

Chemistry Alumni

"Escápate, escoge un libro y vamos para un universo alterno"

(Get away, choose a book an let's go to an alternate universe)

In collaboration with PUCP Library System

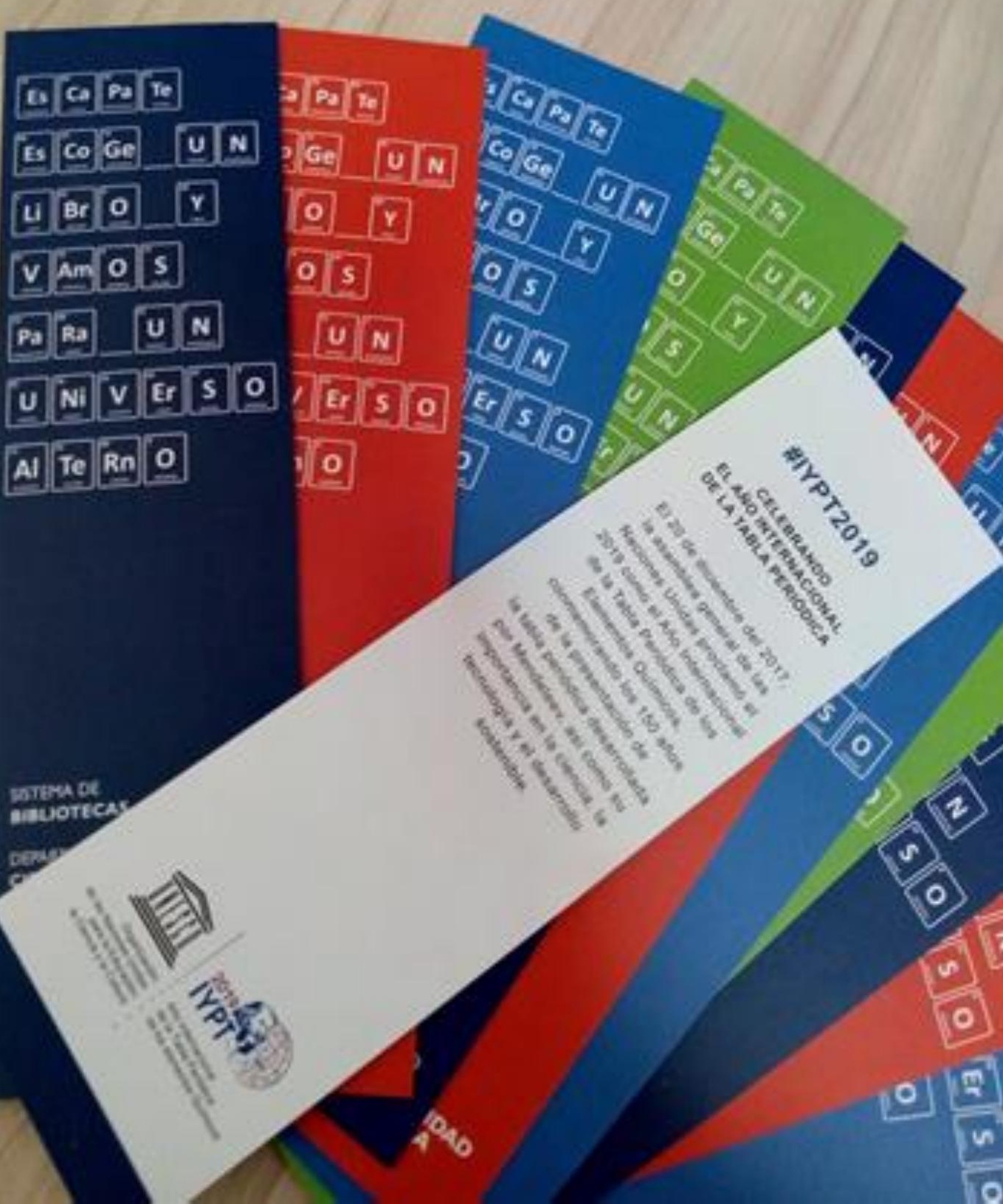




\section{Opening activities in the second semester}

- Participants

General public

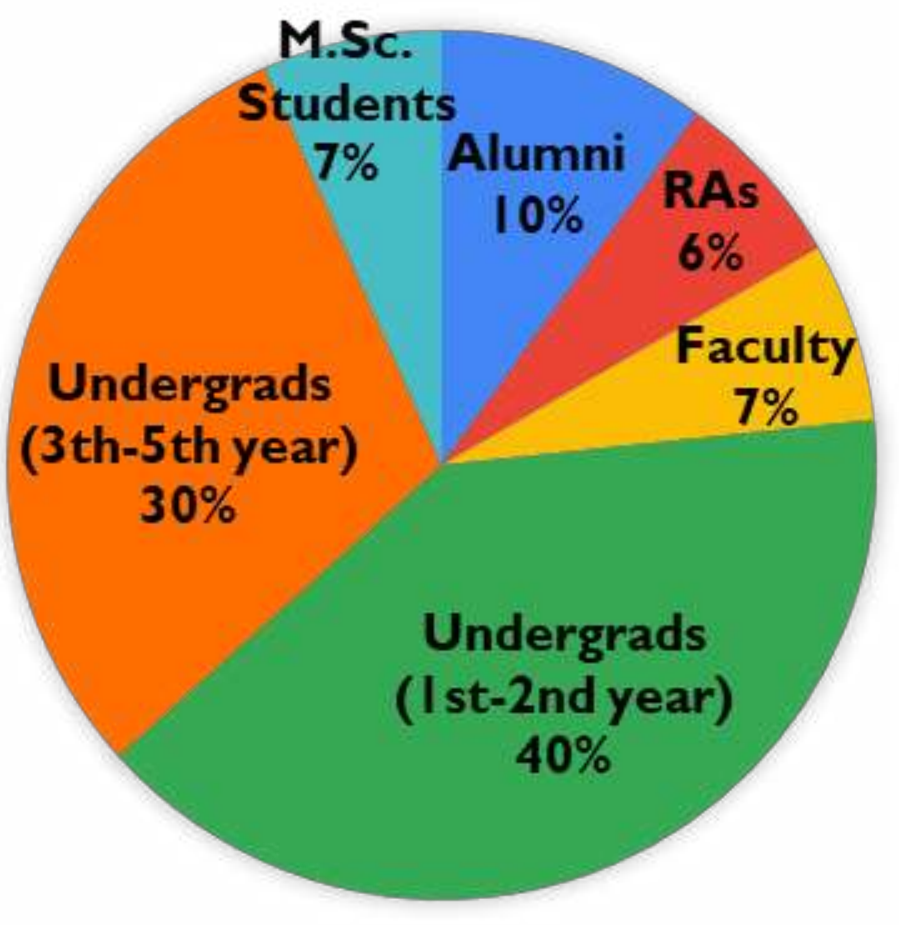

Celebrando los 150 años $B$ de la tabla periódica

Charla: "UNA HISTORIA DE CHOQUES: La evolución

Expositor:

Dr. Luis Ortega San Martín Profesor de Quimica del Departamento
de Ciencias de la PuCP

Premiación de los concursos:

$1{ }^{\circ}$ El desafio de la tabla periódica

$2^{\circ} \mathrm{A}$ la caza de los elementos

Trivia:

"El Kahoot de los elementos" Coffee break y regalos

LUTA

LUGAR: E-102

DíA: Jueves 29 de Agosto

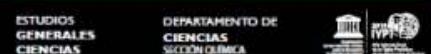

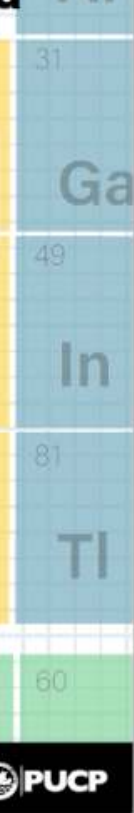

$48 \%$ of participants replied survey $(N=30)$

This pie chart was prepared with information from survey 


\section{Opening activities in the second semester}

\section{Activities}

- Talk

"A history of collisions: the recent evolution of the elements of the periodic table"

- Game

Kahoot trivia game of the elements

- Awards and gifts

Game winners

Winner of the Periodic Table phrase contest and other online quizzes

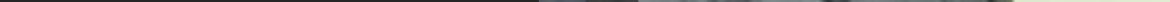




\section{Opening activities in the second semester}

- Results of the Kahoot trivia game

30 participants replied this survey

It was very interesting

It was fun

The prizes were really attractive

I would recommend this to others

It was a good way to learn about the Periodic Table of Elements

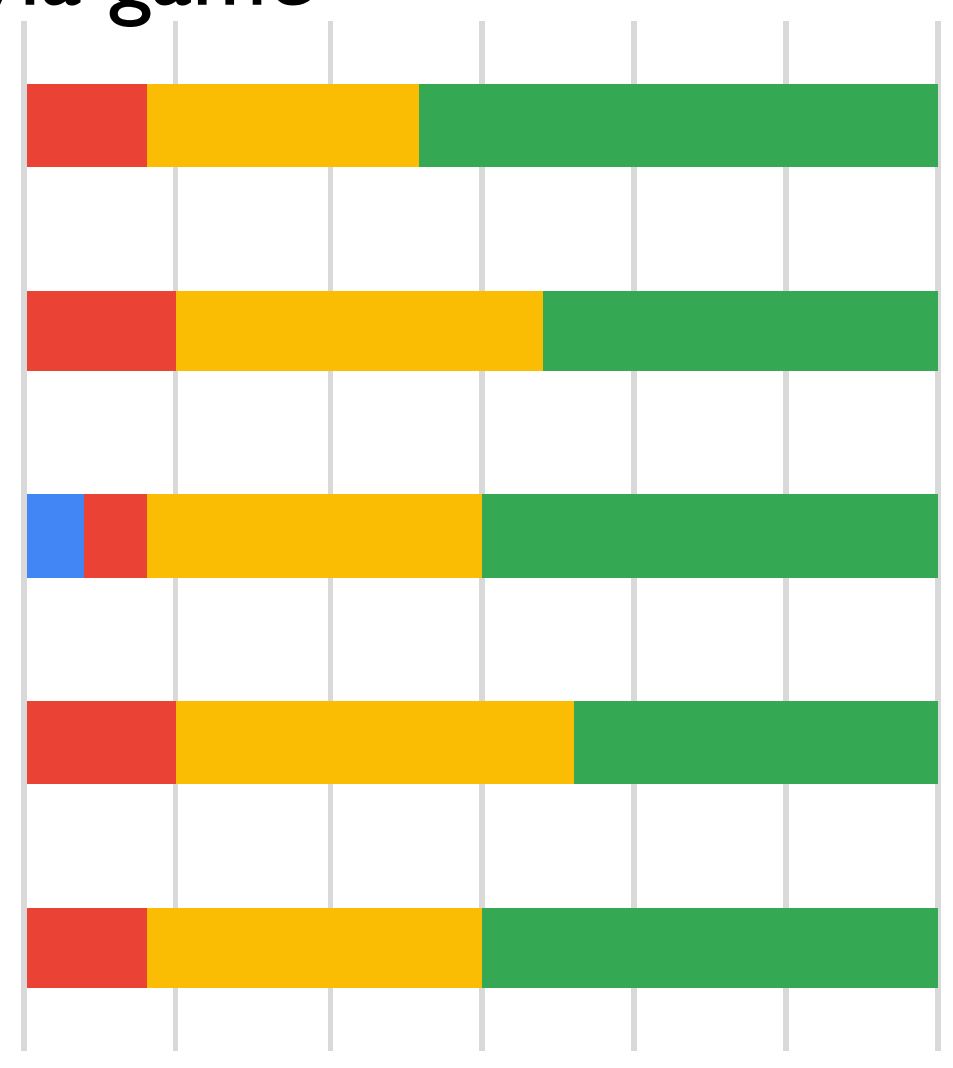

strongly disagree $\square 1 \square 2 \square 3 \square 4$ strongly agree 


\section{Opening activities in the second semester}

- Results of the talk

It was a good way to use my time

It was very interesting

It was a good way to learn about the Periodic Table of Elements
30 participants replied this survey

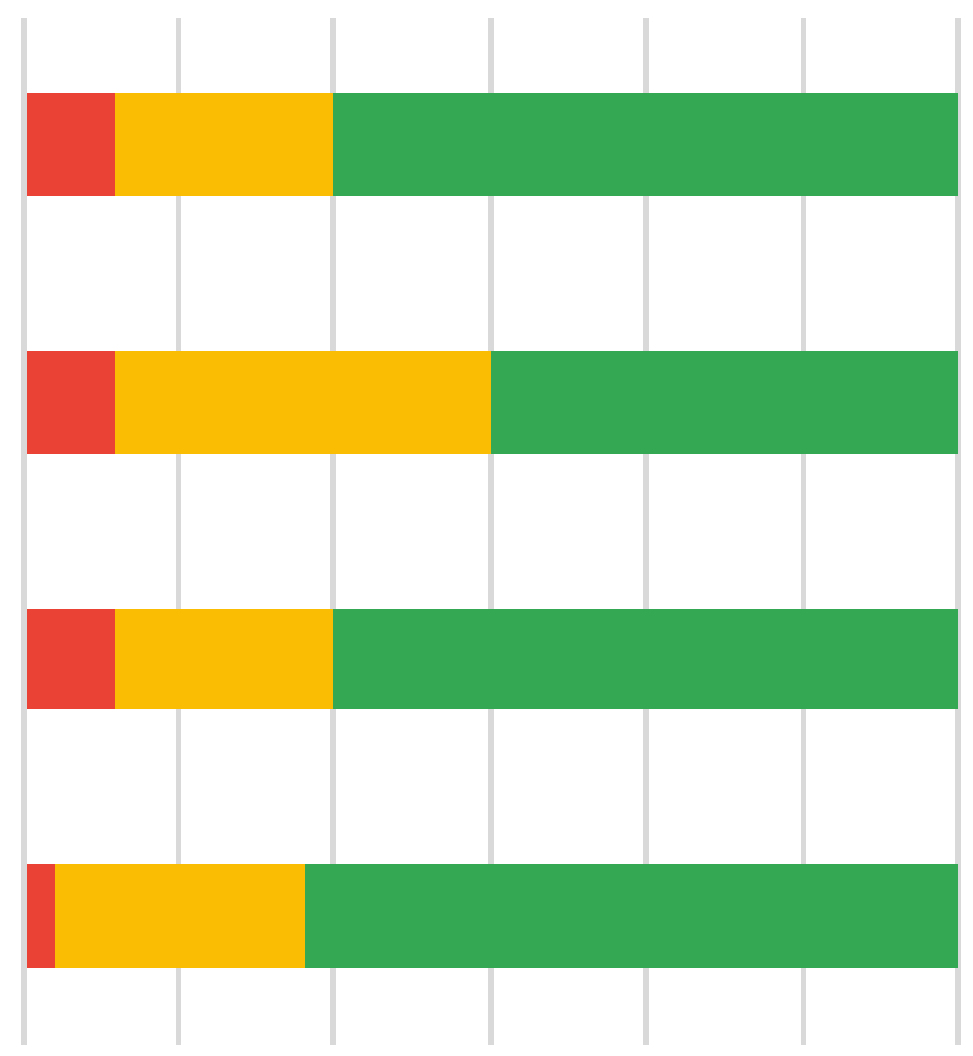




\section{Periodic Table escape room}

- Participants

students, faculty \& staff

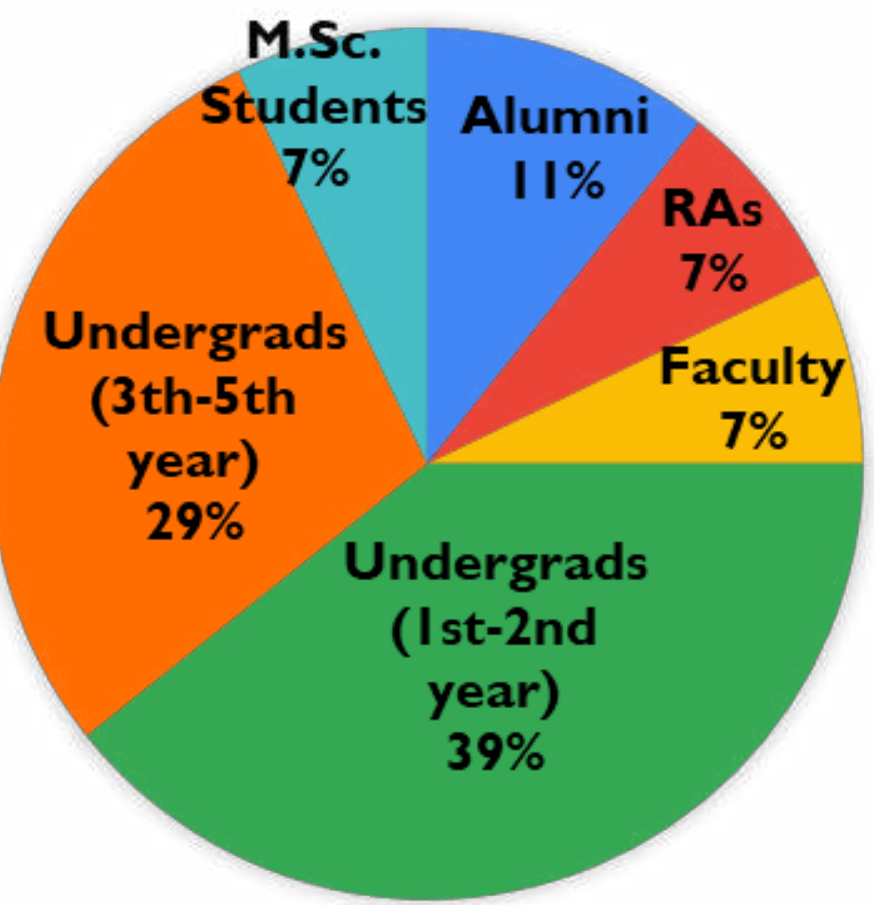

$\#$ of preregistered people $=60$

$56 \%$ of participants replied survey $(N=28)$

This pie chart was prepared with information from survey
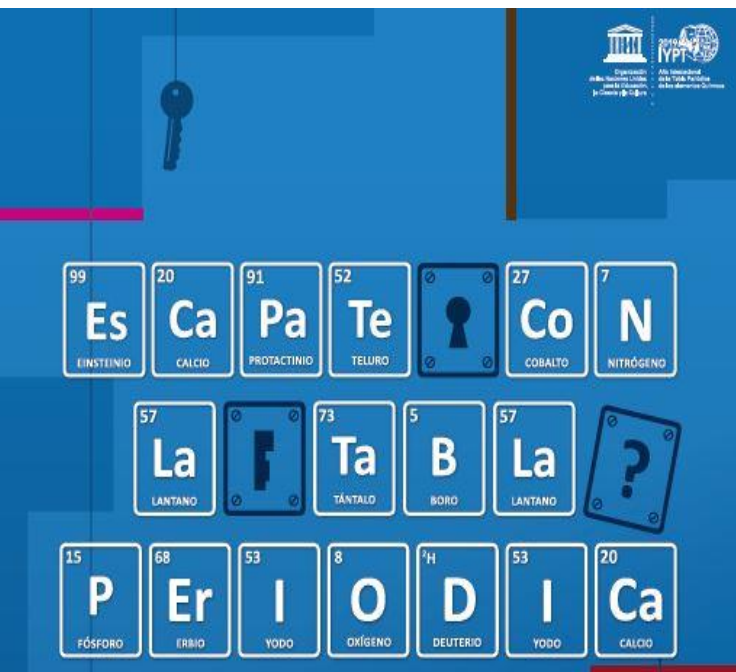

Jueves 05 de septiembre 12:00 pm/ Edificio de Química

Desde la Seccción Quimica hemos organizado un ESCAPE ROOM para que pongas a prueba tus conocimientos sobre la Tabla Periódica y aprendas mucho más. Habrá diversión, regalos, pizza y mucho más. ilnscriBeTe! 


\section{Periodic Table escape room}

Tasks

- Memory game

- Find the picture

Who discovered $\mathrm{Ce}$ ?

- Q \& A

Find the hidden phrase

- Periodic Table puzzle

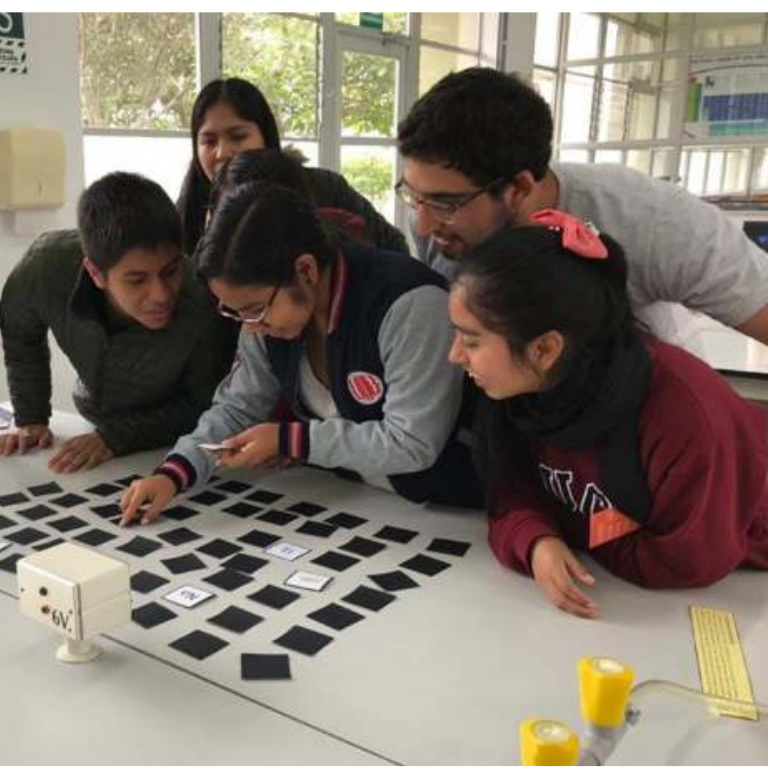




\section{Periodic Table escape room}

- Results

It was a good way to use my time

It was a good way to know people

I would recommend this to others

It was a good way to learn about the Periodic Table of Elements

28 participants replied this survey

It was fun

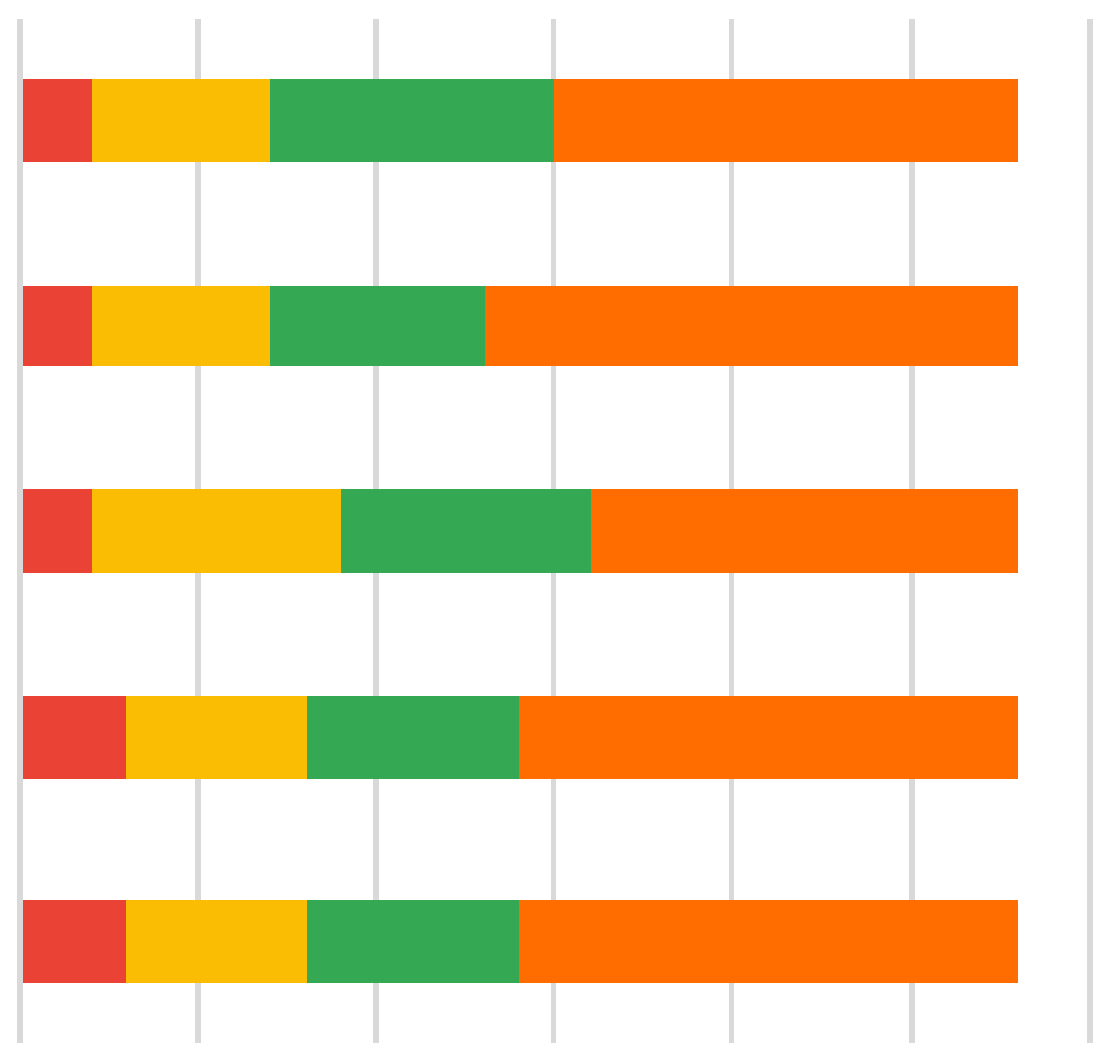

strongly disagree $\square \mid \square 2 \square 3 \square 4 \square 5$ strongly agree 


\section{Periodic Table Bingo}

- Participants

students, faculty \& staff

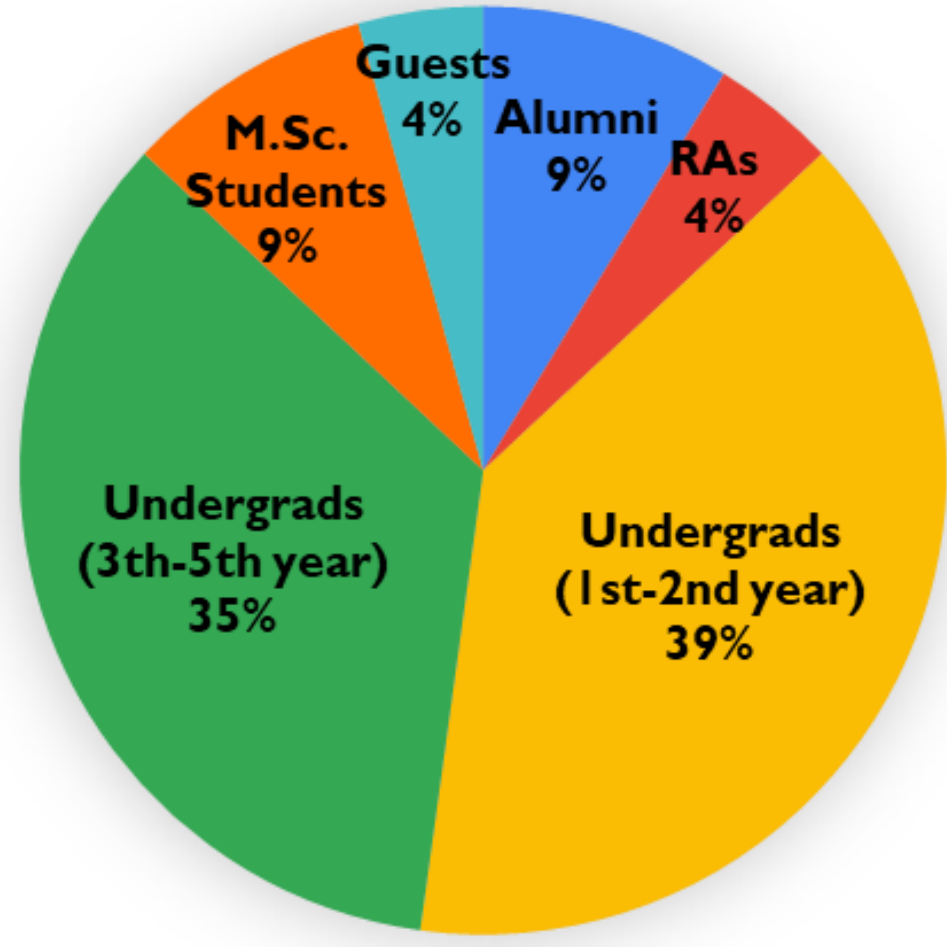

$85 \%$ of participants replied survey $(N=23)$

This pie chart was prepared with information from survey

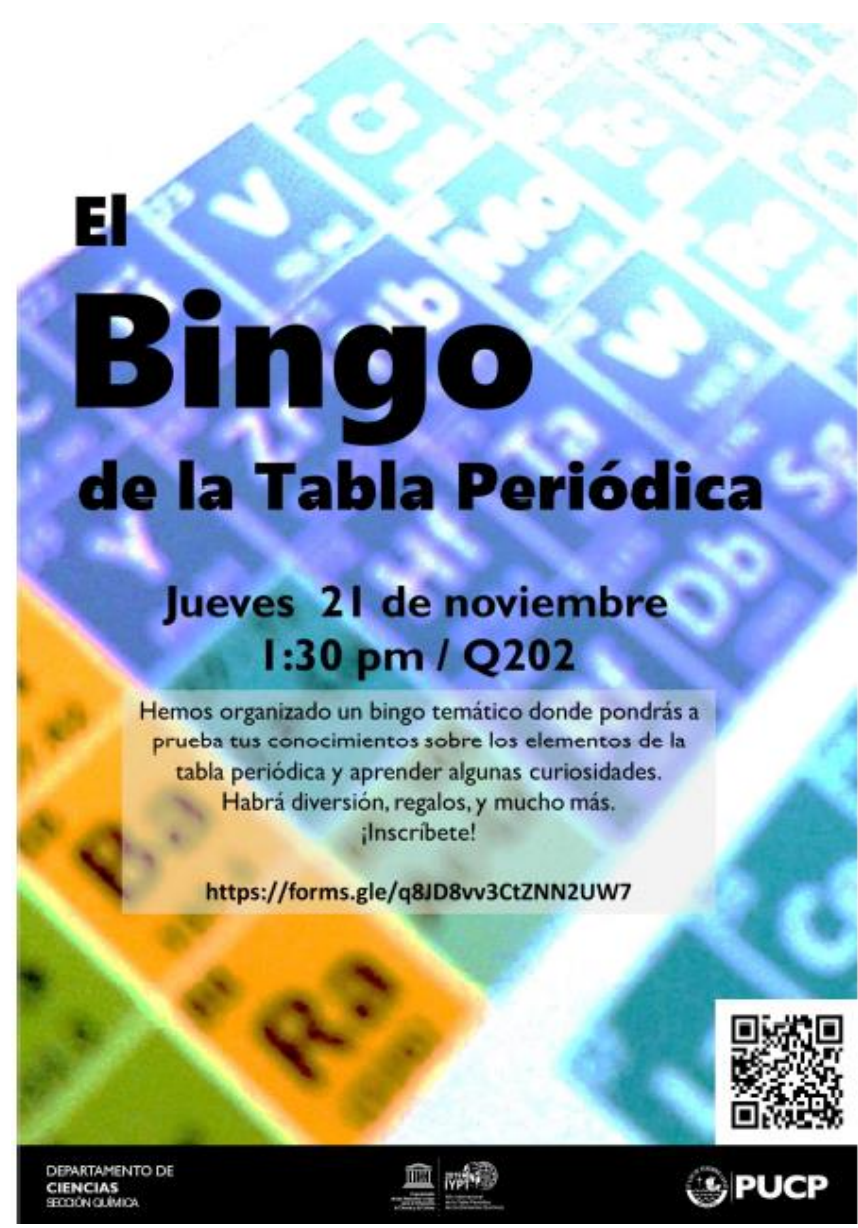

www.edu.rsc.org/resources 


\section{Periodic Table Bingo}

- Results

It was a good way to use my time

It was a good way to know people

I would recommend this to others

It was a good way to learn about the Periodic Table of Elements

23 participants replied this survey

It was fun

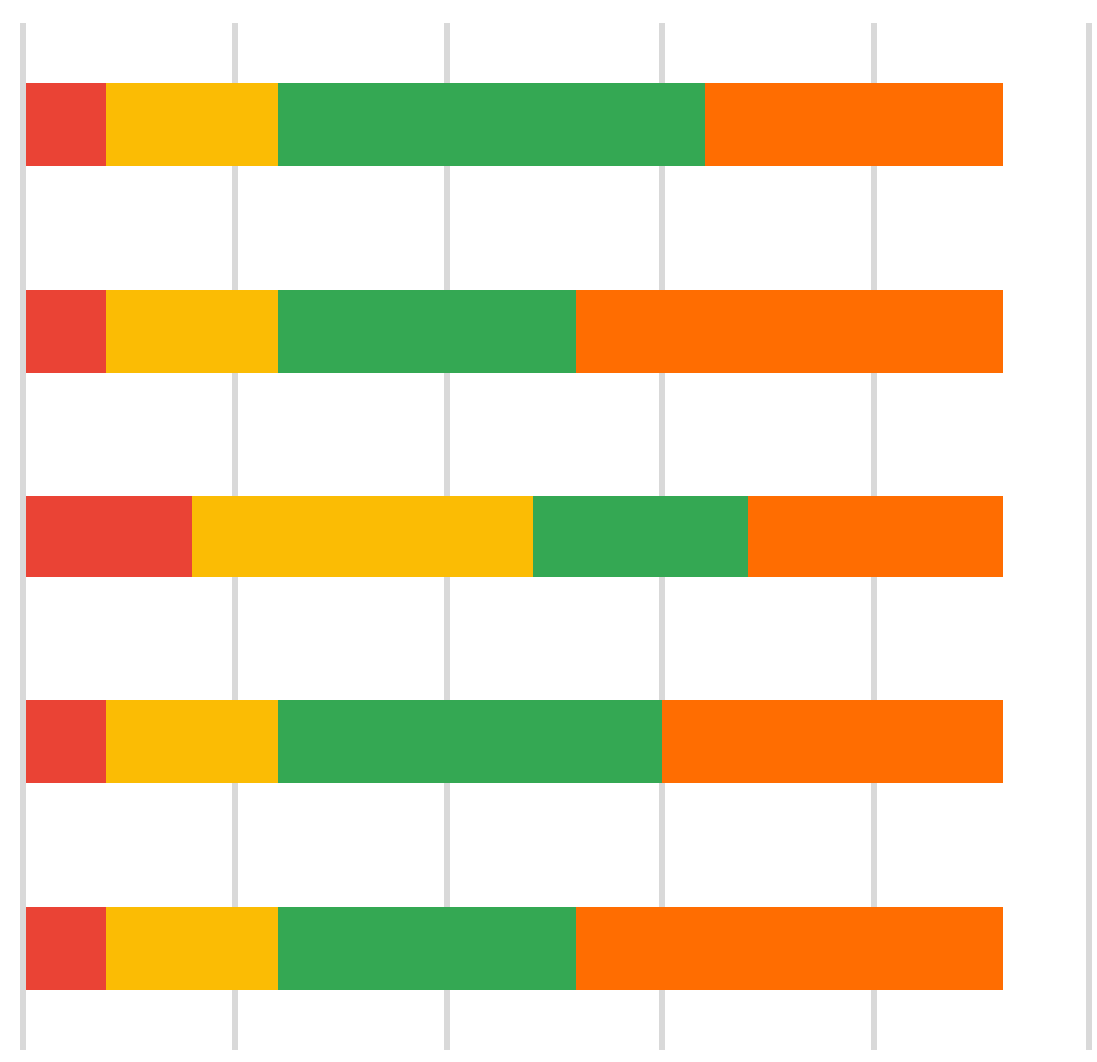

strongly disagree $\square 1 \square 2 \square 3 \square 4 \square 5$ strongly agree 


\section{Periodic Table Games}

- Participants

Participants from the basic level of the National Chemistry Olympiad, their parents and instructors

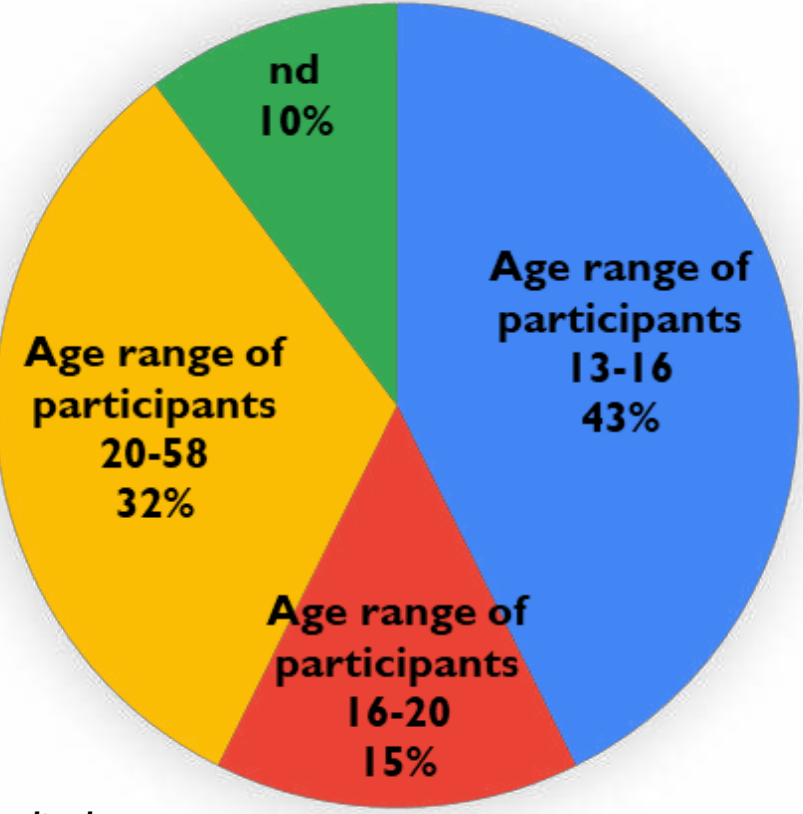

16-20

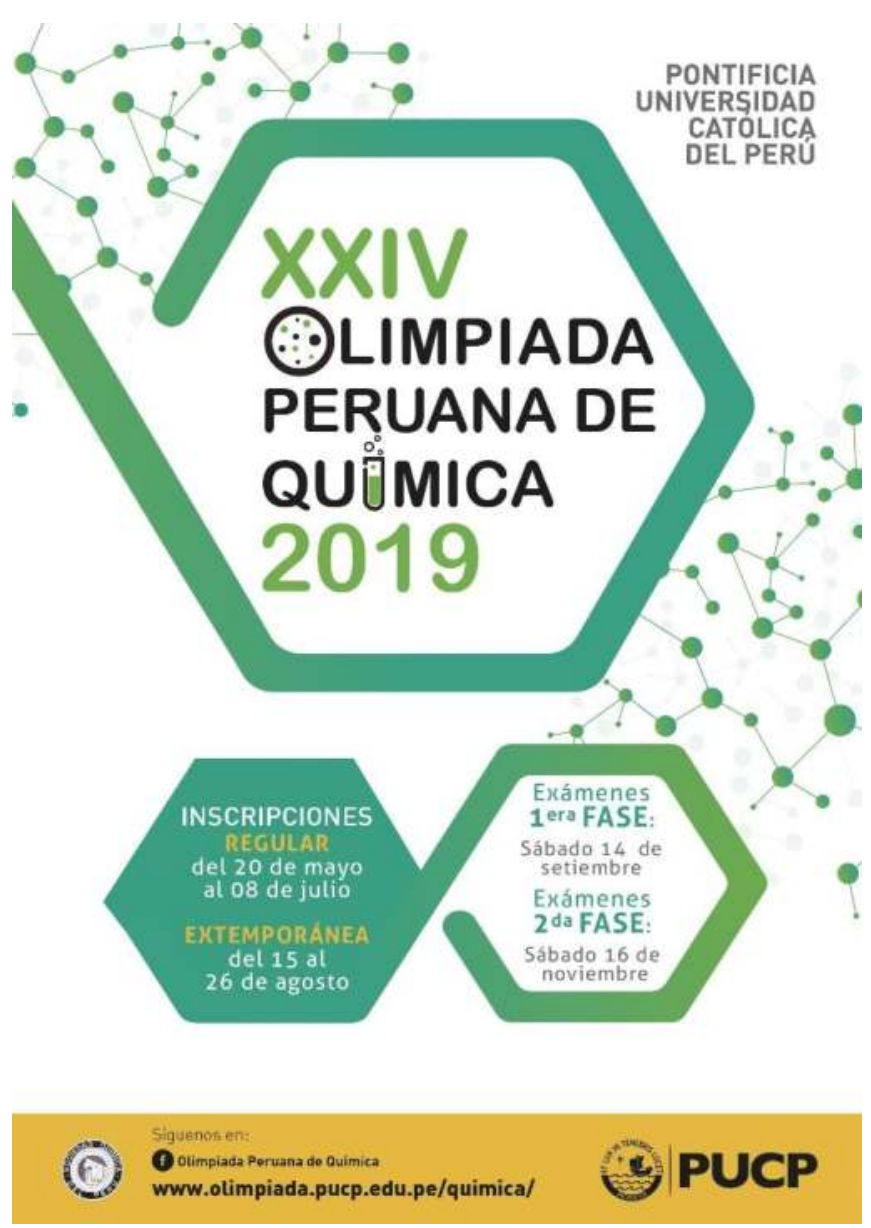

http://olimpiada.pucp.edu.pe/quimica/ 


\section{Periodic Table games}

- Periodic Table memory game

- Resource from escape room

- An online app was used to manage the game https://www.bookwidgets.com/
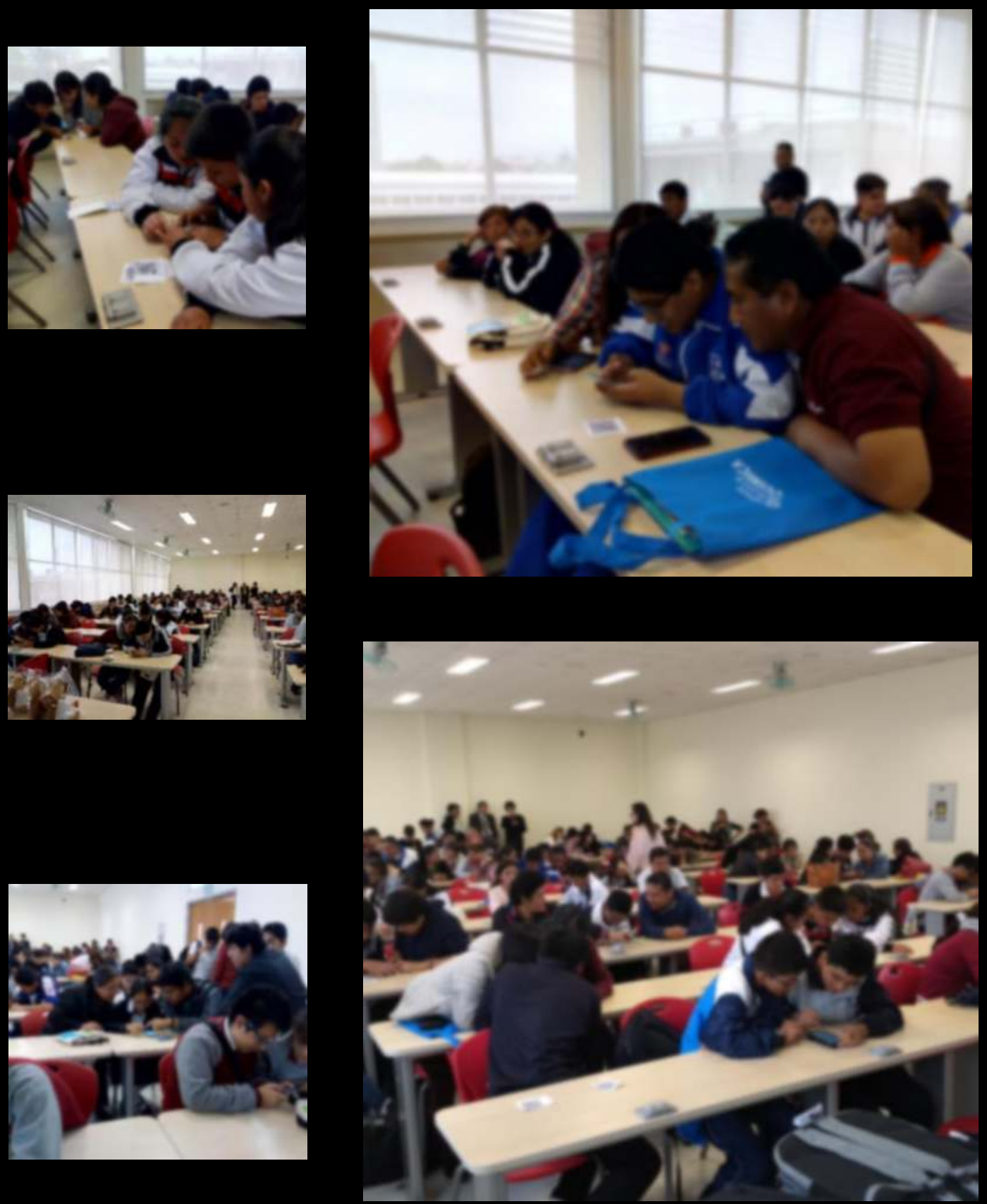

- Periodic Table Bingo

- Resource from RSC www.edu.rsc.org/resources
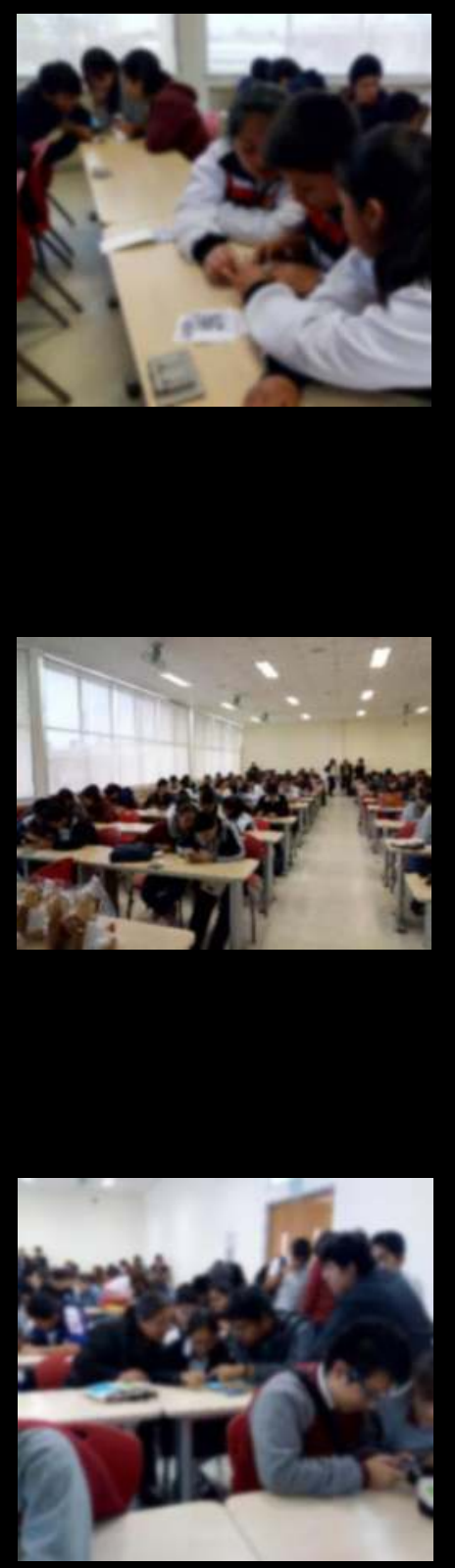


\section{Periodic Table Games}

\section{- Results}

It was a good way to use my time

It was a good way to know people

I would recommend this to others

It was a good way to learn about the Periodic Table of Elements

68 participants replied this survey

It was fun

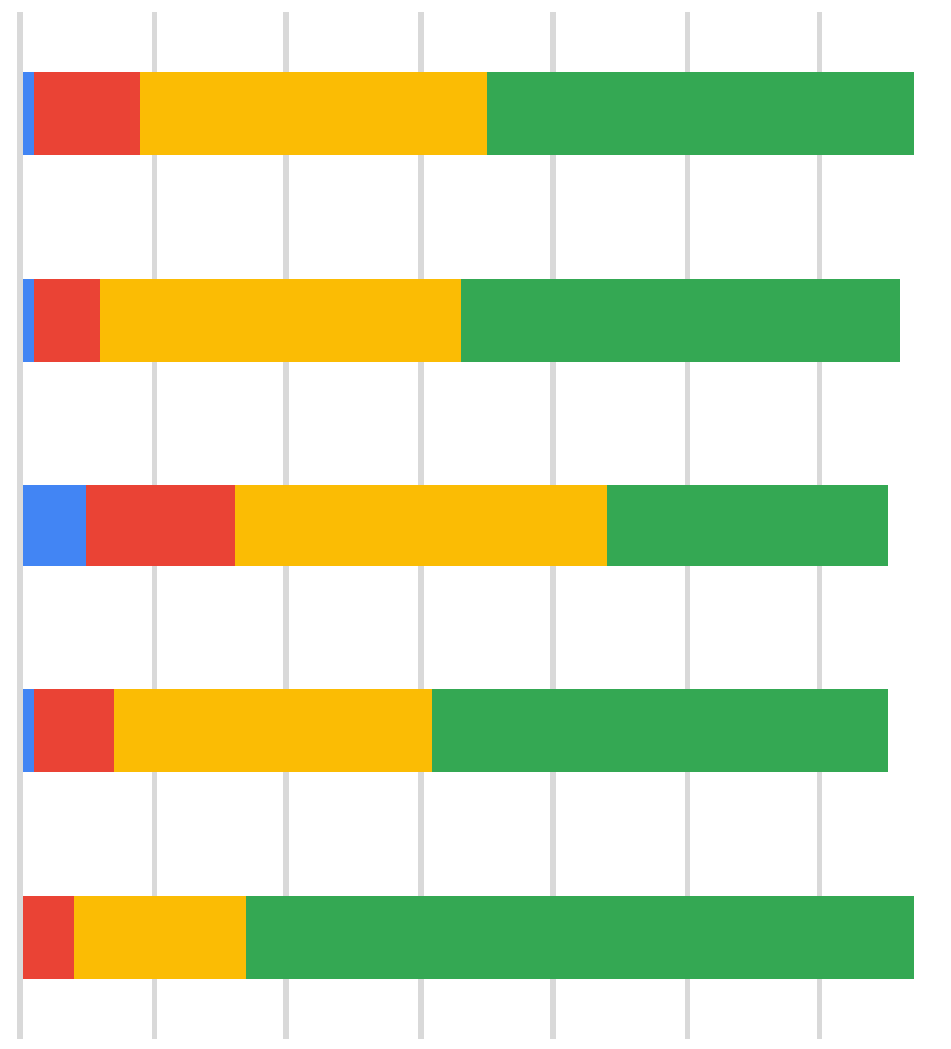

strongly disagree $\square 1 \square 2 \square 3 \square 4 \quad$ strongly agree 


\section{Periodic Table Games}

- Results

68 participants replied this survey

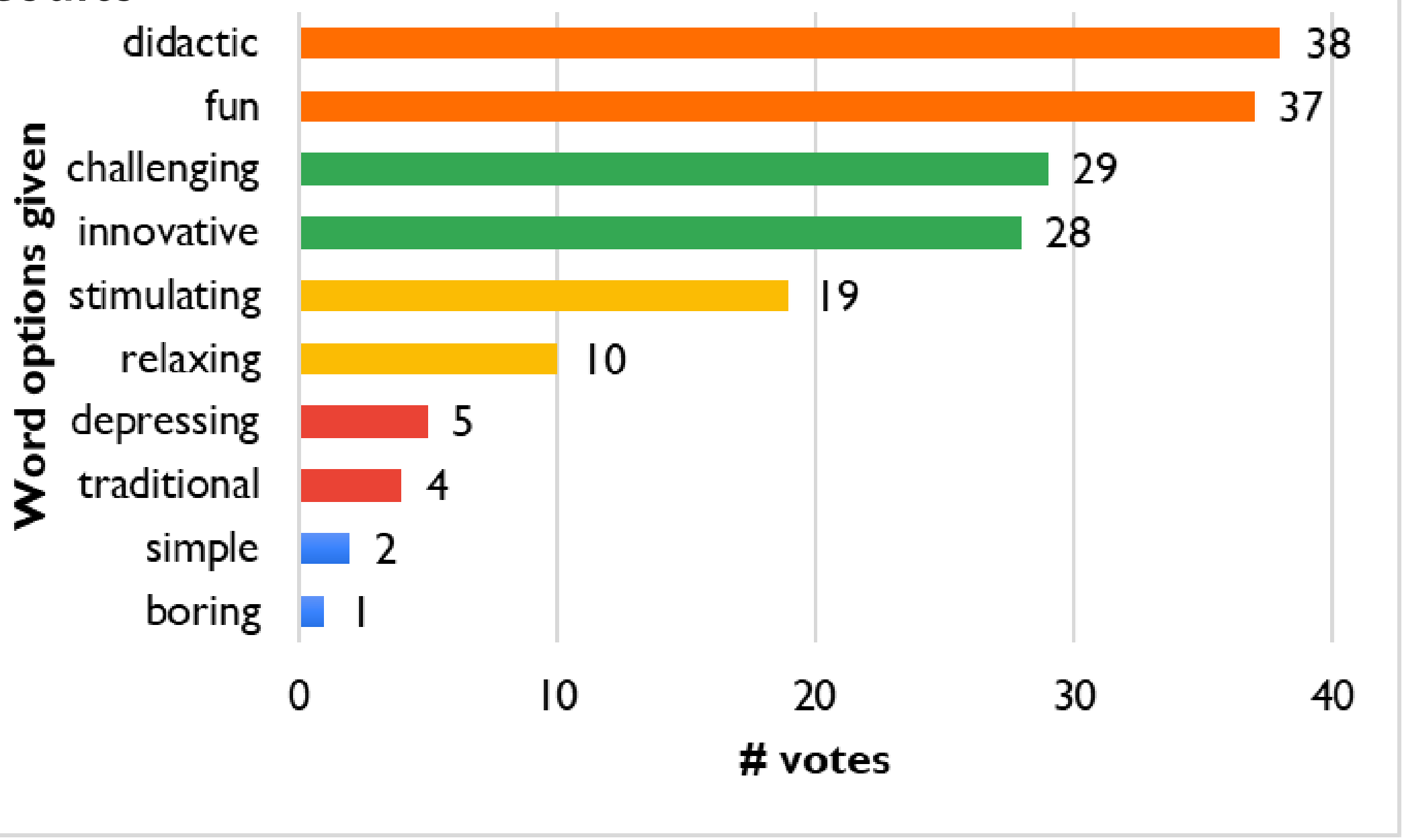




\section{Periodic Table Games}

\section{- Results}

\section{- Some of their comments}

“...Keep innovating! This is really good!”

“...Excellent! Next year I will come back with my other kids"

"...Very nice game! I learned new facts about the elements of the Periodic Table"

"...This is a really good way to promote interest in chemistry!"

"...Send us by email more games to solve"

“...Excellent! Thank you for showing us new and didactic games" 


\section{Closing event of the IYPT}

- Participants

\section{General public}

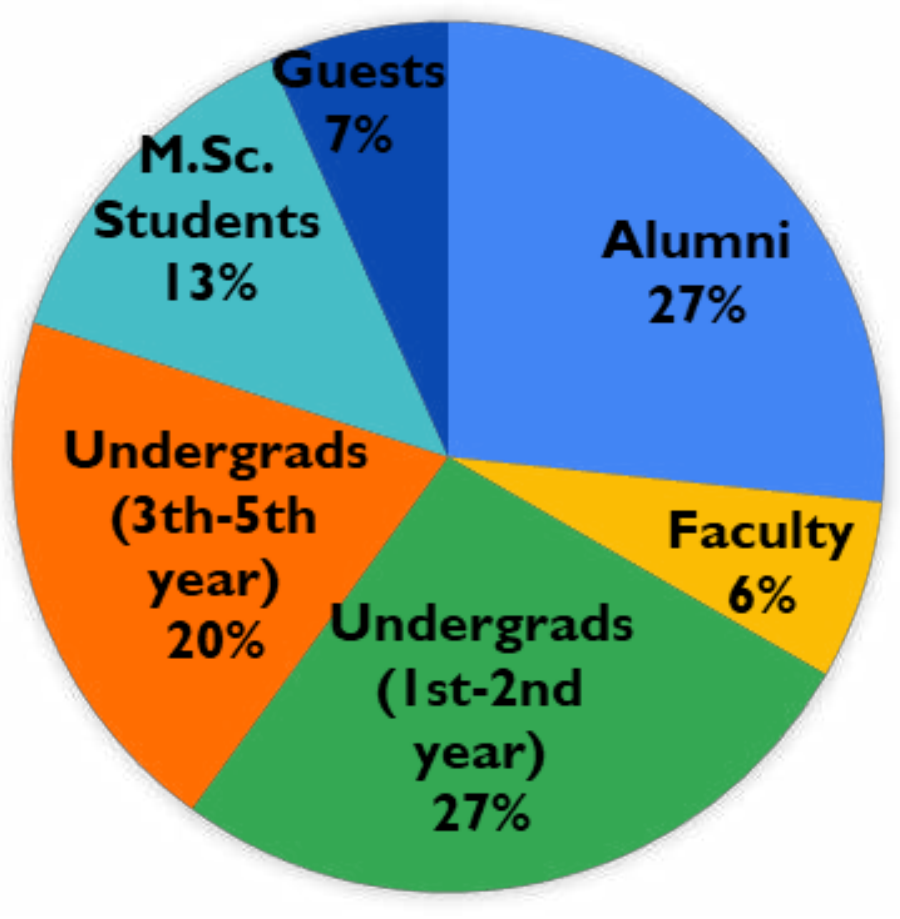

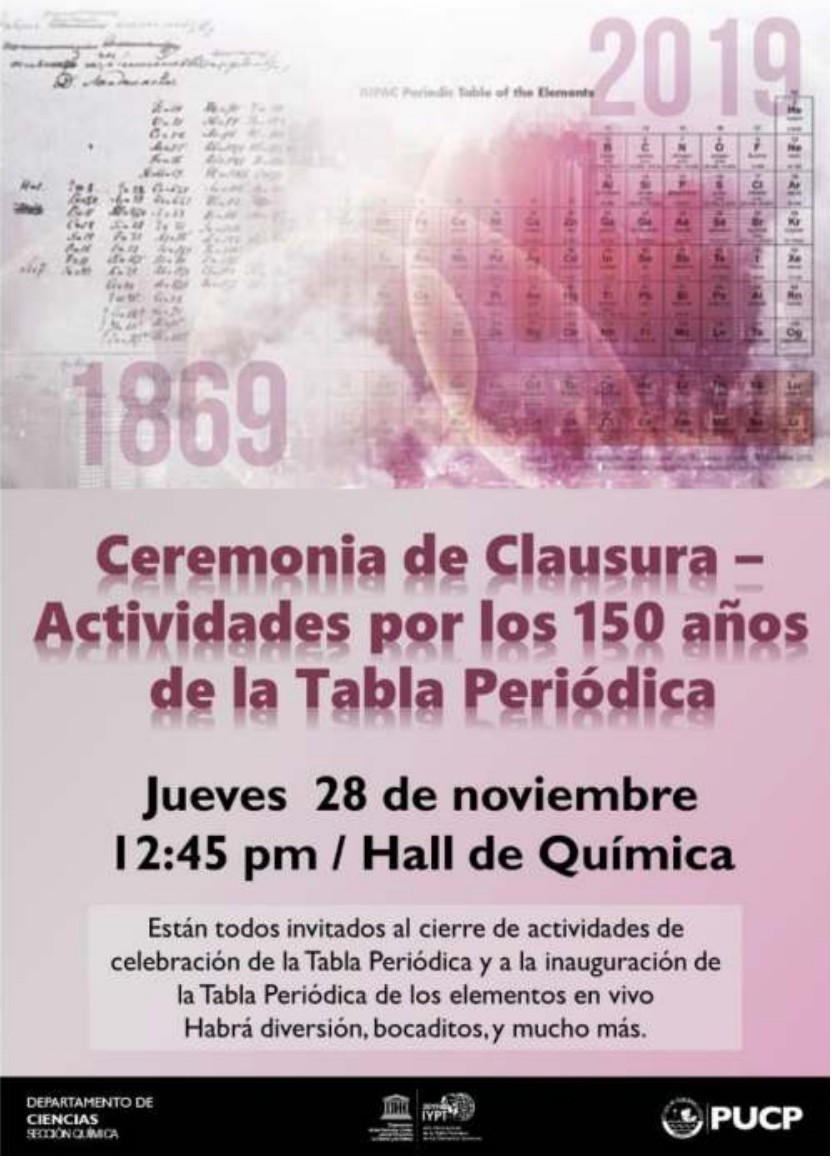

I5 participants replied survey

This pie chart was prepared with information from survey 


\section{Closing event of the IYPT}

- Construction of a periodic table with real elements

Collaboration of students, faculty, alumni, our glass workshop, other research groups, collaborators, local distributors, etc.

- Periodic table raffle

- All participants helped to build a Periodic Table cookie-board
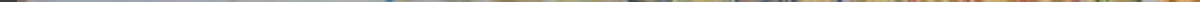


\section{Closing event of the IYPT}

\section{- Results}

It was a good way to use my time

It was fun

It was a good way to know people

I would recommend this to others

It was a good way to learn about the Periodic Table of Elements

It was a good way to conclude the activities of IYPT

It was a good way to learn a bit more about the Chemistry Dept.
I5 participants replied this survey

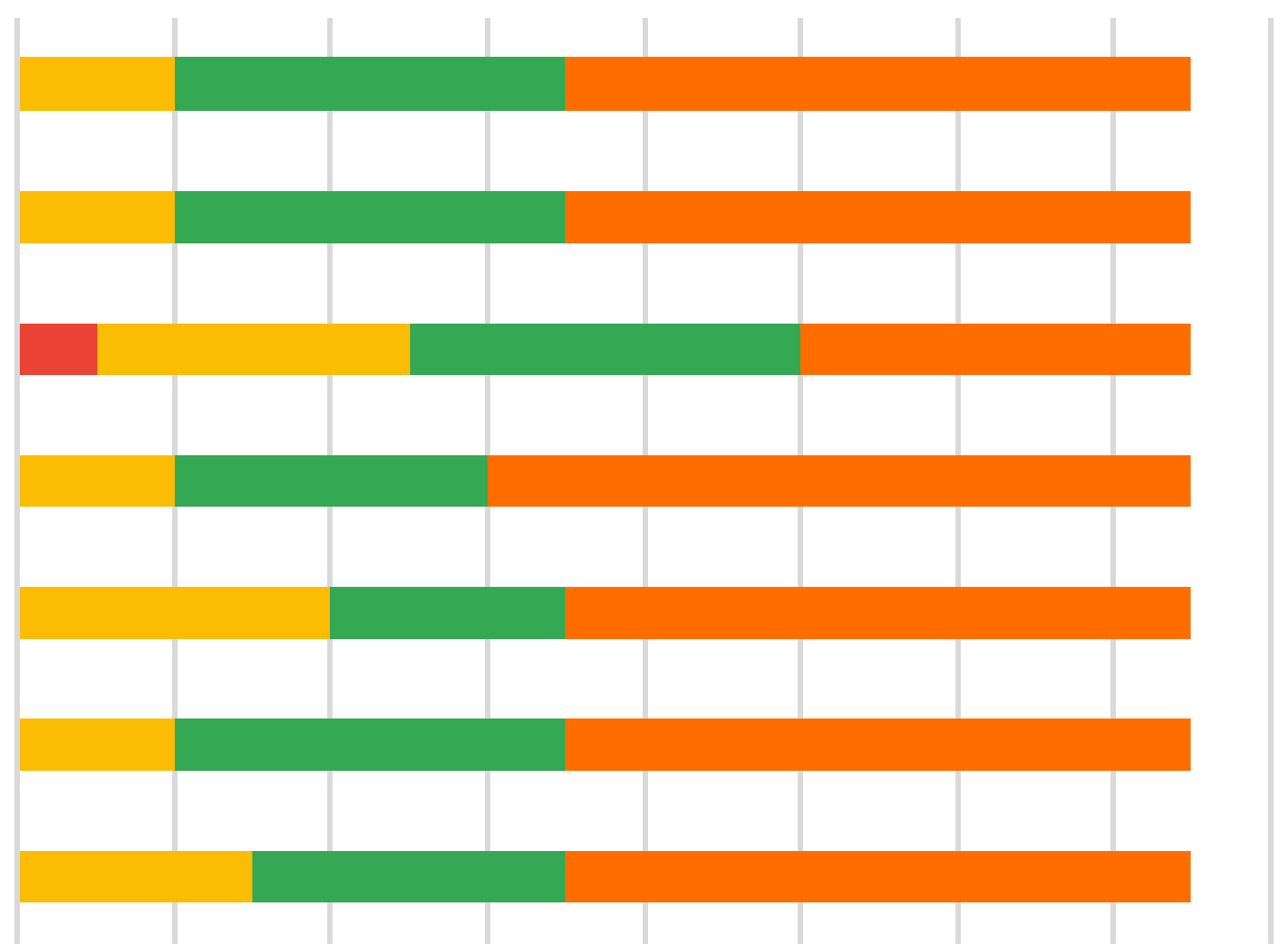

strongly disagree $\square \square 2 \square 3 \square 4 \square 5$ strongly agree 


\section{Final Remarks}

- An improvement in our communication channels with public and other members of our community (students, staff, other departments, alumni, local companies and general audience)

- Surveys suggest a good acceptance from participants and an alternative way to learn a little bit about the Periodic Table and the role Chemistry has in our daily lives

- We continue to try reaching out to others through social media 


\section{Acknowledgements}

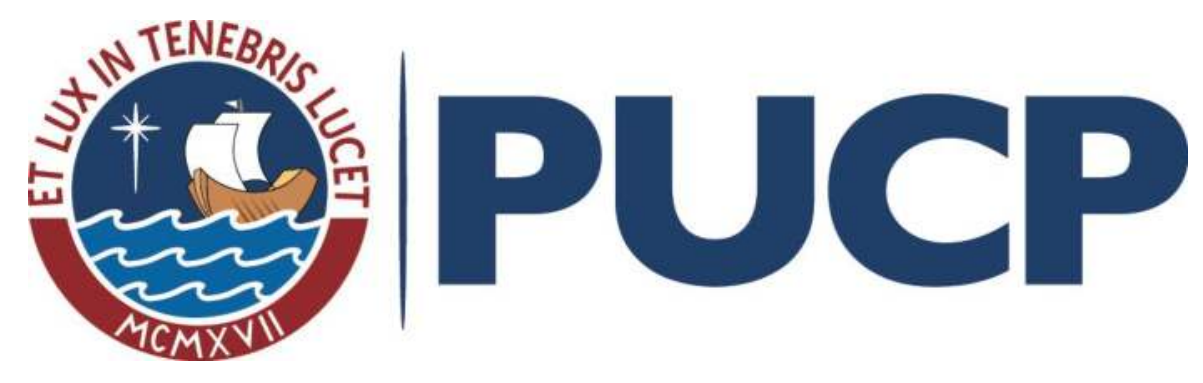

DEPARTAMENTO ACADÉMICO DE CIENCIAS

Academic Department of Science

PORTAL DE COMUNICACIÓN

PUCP Library system INSTITUCIONAL

Direction of Institutional Communication

SISTEMA DE BIBLIOTECAS

Members from the Chemistry community at PUCP

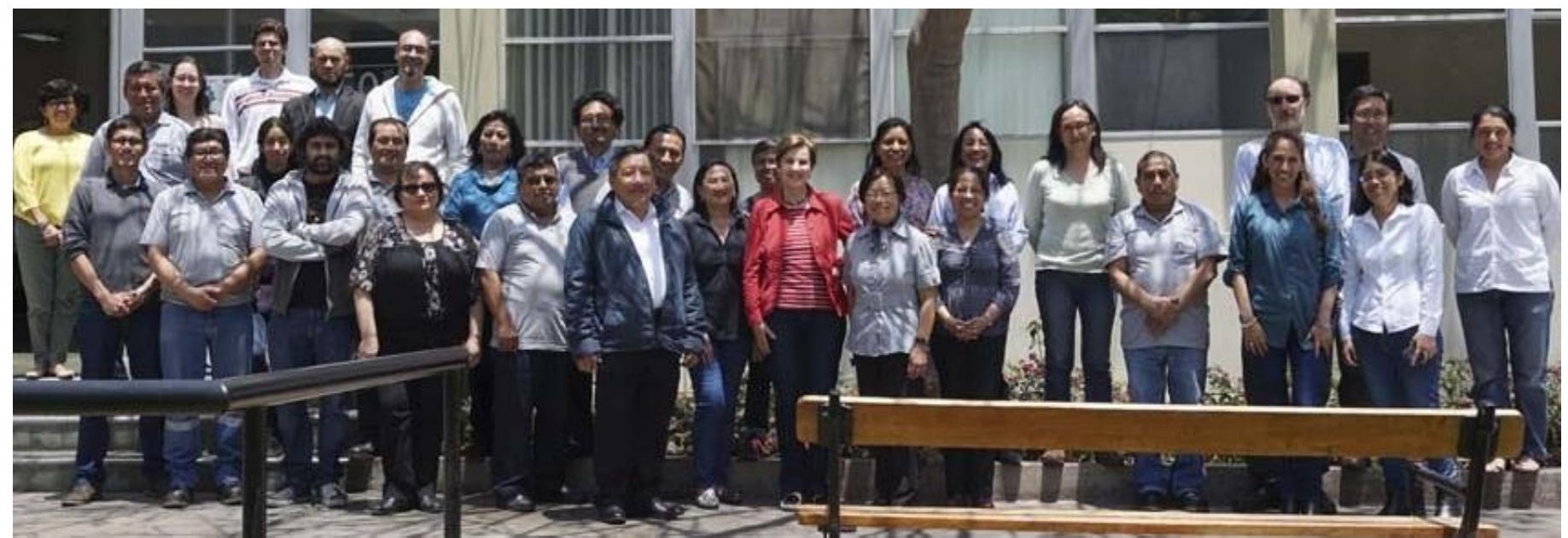

